\title{
GEOLOGY OF RIGAUD MOUNTAIN, CANADA
}

\author{
BY OSMOND EDGAR LE ROY*
}

(Read before the Society December 28, 1900)

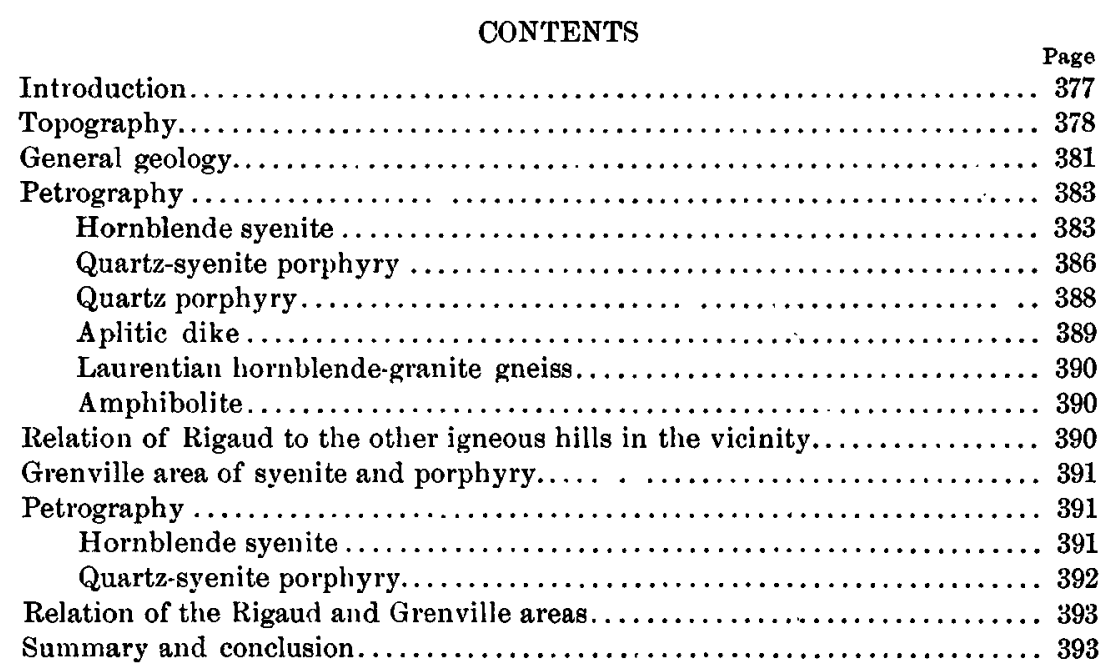

\section{INTRODUCTION}

Rigaud mountain is situated in the northwestern part of the county of Vaudreuil, Province of Quebec, Canada, and includes in its area the parish of Saint George and parts of the parishes of Rigaud, Saint Redempteur, and Sainte Marthe. It is the most western of a line of hills of igneous origin, which, in the vicinity of Montreal, forms the principal topographic feature of the eastern part of the Paleozoic plain of central Canada. These hills-locally termed mountains-are at*no great distance from the border of the V-shaped Laurentian protaxis, and follow a line of disturbance which is almost at right angles to the trend of the Notre Dame range. In westward succession there are Shefford, Yamaska,

* Introduced by F. D. Adams. 
Rougemont, Beloeil, Montarville, Mount Royal, and Rigaud. The hills of Brome, lying south of Shefford, and mount Johnson, south of Beloeil, are on another line, but evidently belong to the same series. Sir William Logan has described them as being of post-Silurian age, and from the field relations of those recently examined such has been found to be the case, with the exception of Rigaud, whose age is doubtful, owing to the fact that the contact between the Paleozoic and igneous rocks is wholly concealed by drift. In the absence, then, of any direct proof such as a contact would afford, it was thought by the writer that possibly the petrographical character of the rocks would show Rigaud to be closely related to the other hills. With this end in view, a detailed examination of Rigaud mountain was made, and the following pages contain the results of the field and laboratory work, together with the conclusions arrived at.

\section{TOPOGRAPHY}

Rigaud, owing to the general levelness of the immediate surrounding country, occupies a more prominent position than its height would otherwise warrant. In shape the mountain is roughly oblong, and has an aren of about 15 square miles. The topographic features closely resemble those of the neighboring Isaurentian-rounded ridges and knobs of rock, partly bare, partly wooded, with drift-floored valleys of varying width between. The marginal area and some parts of the interior are well forested, otherwise the rock is exposed or only covered by a scrubby growth. In the west the mountain consists of a series of interrupted ridges, and longer axes of which have an east-and-west trend. The central part is rather plateau-like in character, and is made up of subordinate elevations of the roche moutonnée type, which exhibit in many instances stoss and lee slopes. On the line between Saint George and Sainte Marthe the plateau terminates in an abrupt slope to the south, and on this line the highest point of the mountain is situated, there attaining a height of 750 feet above sealevel. From this slope southward the area is but little higher than the immediate surrounding country. The eastern part is marked by one ridge, which is continuous throughout the widih of the mountain, and runs in a northeast direction. The valleys between the plateau and principal ridges are comparatively broad, shallow depressions, well drained by intermittent creeks into the rivers à la Graisse and Racquette. They are floored with gravel, sand, and sandy loam, which in recent cuts show a very even stratification.

The most prominent ridge is the one fronting on the Ottawa river, the western part of which is shown in figure 1 , plate 33 . Its average elevation is about 550 feet, but attains at its peak a height of 704 feet above 


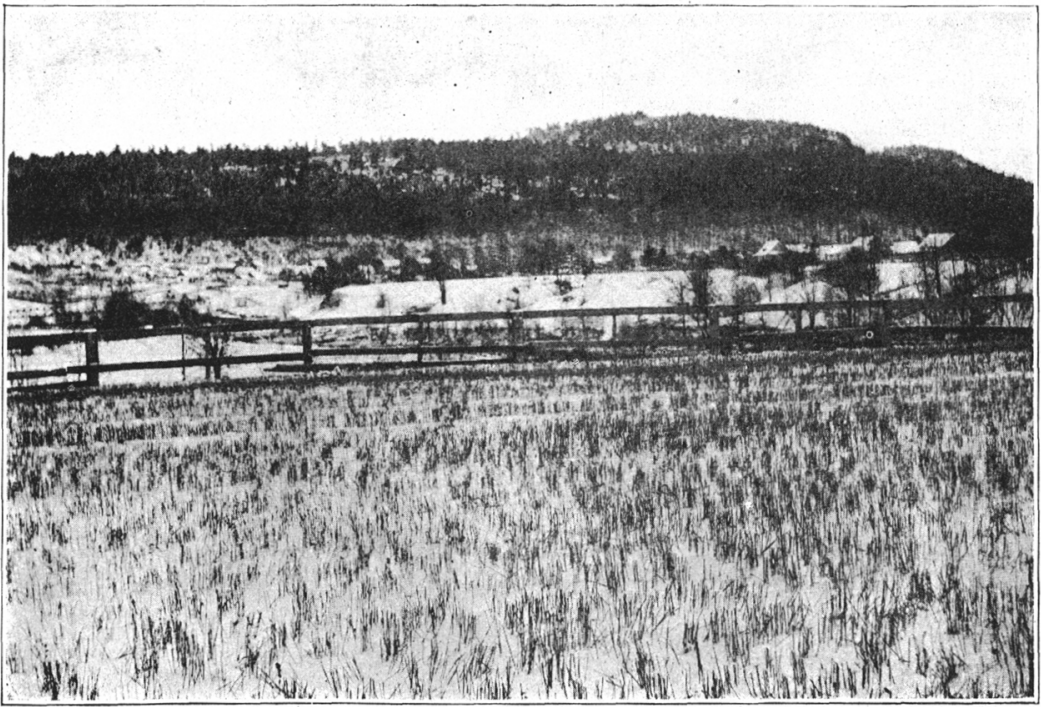

Figure 1.-Rigaud Mountain, western Part of the northern Ridge

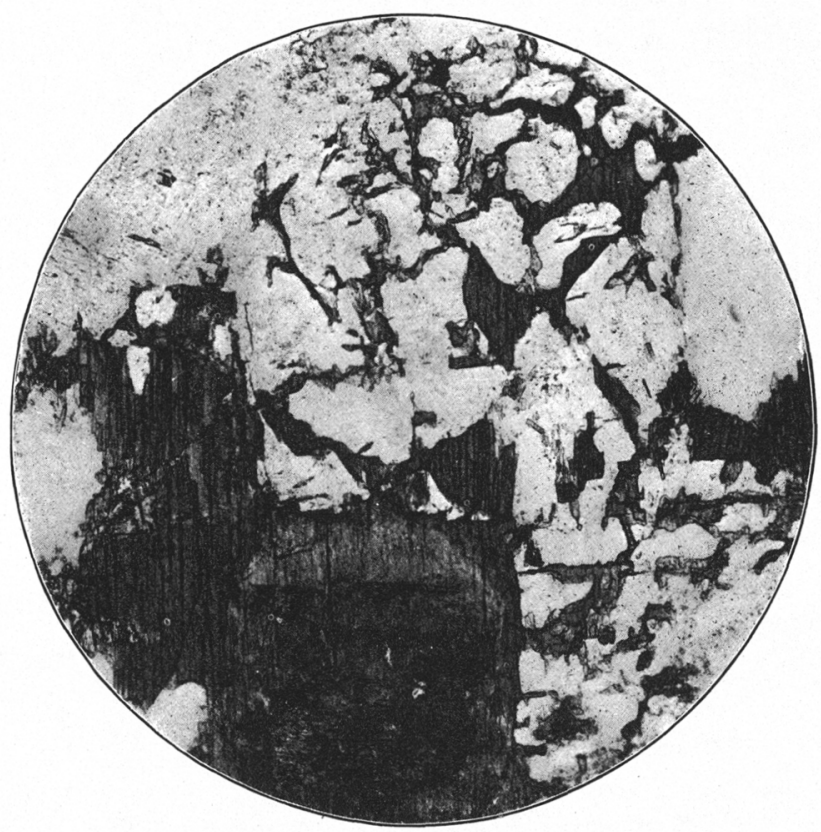

Figure 2.-Microphotograph of Rigaud Hornblende-Syenite

Dark constituent is hornblende intergrown with feldspar in a graphic manner Zonal alteration of hornblende also seen. Ordinary light $\times 44$ 

sealevel. The slope to the north is quite rugged, and many small precipices from 15 to 40 feet high have been developed, due to the ease with which the rock joints. The particular interest attached to this slope, however, is due to the occurrence of two large boulder deposits. One of these fills a depression just east of the peak, and tinged by local tradition is popularly known as the Devils garden. It is an irregular oval in form, with the longer axis running southwest, and occupies an area of about 50 acres. Higher parts of the mountain inclose it on all sides

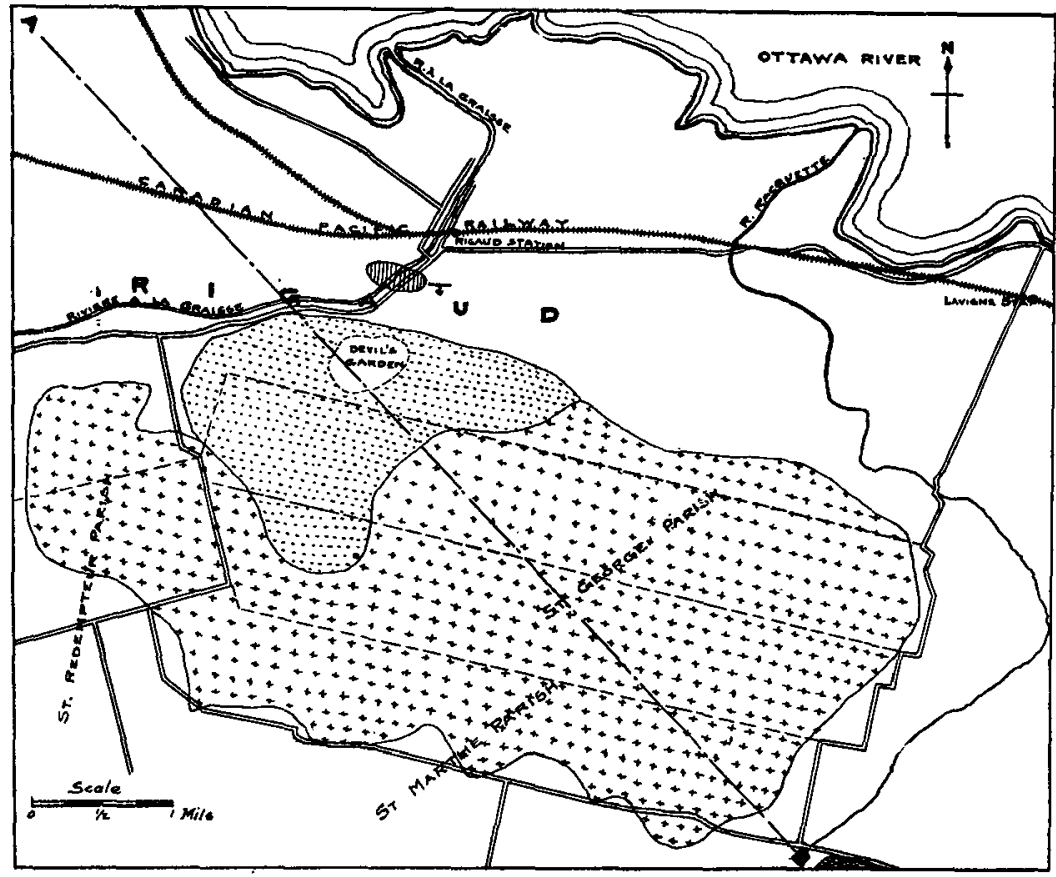

STEMite $\square$ Ponmurer

Frauke 1.-Map of Rigaud Mountain, Canada.

except the northern, which is lower, especially in the northeast, where the deposit terminates in a rather abrupt fall of about 20 feet. The boulders are subangular or well rounded, from 5 to 20 inches in diameter, and are arranged in a series of parallel ridges which run in a direction at right angles to the longer axis. These ridges when well marked have convex crests, thus giving to the garden an undulating appearance when viewed broadly; they are from 4 to 6 feet high and from 20 to 30 yards apart. In some parts of the area the ridges are very indistinct, and 
it is impossible to state the exact number, though it is probably in the neighborhood of 25. The garden gradually rises toward the southwest; the difference in level between the lowest and highest ridge is about 125 feet, the former being 350 feet above sealevel. Practically all the boulders are the debris of the mountain in the immediate vicinity, not more than 1 per cent being Paleozoic and Laurentian erratics. The spaces between the boulders are quite empty, and in the northeast part, where the deposit is deepest. several excavations have been made, one of which was continued to the depth of about 20 feet without reaching bed rock or any accumulation of soil in the interspaces. It is probable, however, that the deepest parts do not much exceed 25 feet, as part of the country south is drained under the garden, in wet seasons the trickling of the water being distinctly heard, while on the occasion of one visit running water was noted in the 20 -foot hole.

Separated by but a short distance from the above is the second deposit, which, commencing just below and north of the peak, fills in the triangular area between the porphyry and syenite. 'The ridges are at first irregular and are composed of very large and slightly rounded boulders, but gradually they broaden out and develop into a series as regular and better marked than those of the Devils garden. 'They run in a southwest direction-that is, at right angles to the trend of the ridges of the former deposit. The other characteristics are the same as in the case of the Devils garden, with the exception that this deposit is probably not so deep.

The character of the boulders in the Devils garden is such as to show that they came from the mountain immediately to the east, while those composing the second deposit were derived from the cliffs below the peak. With reference to the origin, it was thought both deposits were formed by the action of the waves during the post-Glacial submergence, and that, owing to a comparatively rapid rise of the land and the exposed position the mountain would then occupy, the finer detritus was washed out and deposited in the gravel and sand terraces which now flank the mountain in this vicinity. If that were the origin, then the Devils garden would have the character of a pocket beach and the second deposit that of a spit. The oljection that has been made to the above is that no beaches now in process of formation show the above characteristics, there always being some packing of the finer detritus between the boulders. It has therefore been suggested that during the Glacial period, when the ice-sheet impinged against the projecting and prominent parts of the mountains, lines of drainage were developed owing to the obstructions encountered, and that the courses of these glacial streams were through the depressions, one to the east and the other to 
the west of the peak. The torrents of water from the melting ice would partially or wholly round the fragments of rock, and the currents, being of sufficient force and volume, would carry away all the finer material and deposit it farther south. After the retreat of the ice-sheet, and during the subsequent submergence, these boulder plains would to some extent have been worked over by wave action, and thus arranged in successive parallel ridges or beaches as they are found at present. This dual origin seems to be the most probable, and more fully accounts for peculiarities of deposition which are characteristic of both deposits than if the whole work were ascribed to wave action alone.

Another point of interest, and worthy of mention, is a fissure spring which occurs on the northern ridge about half a mile east of the Devils garden. It is 500 feet above sealevel, and from its height and its being unaffected by seasonal variations it would appear that the water supply is derived from some higher land, in all probability the neighboring Laurentian country.

\section{Gleneral Ghology}

The greater part of Rigaud mountain is composed of hornblendesyenite, which is pierced in the north western part by an intrusive mass of porphyry. 'The syenite is a uniform, massive, coarse grained rock, the exposed surfaces of which vary in color from pale red to grayish white. The rock joints into rough rectangular blocks, which are very numerous along the eastern margin. Red chert veins cutting the syenite are common in all parts of the area. They never exceed half an inch in width, and follow irregular courses, from a few inches up to a hundred feet in length. Along the north western margin a miarolitic structure is developed, evidently quite similar in character to that found in the Baveno granite on lake Maggiore. The cavities are of all sizes, from the most minute up to those having a diameter of 2 or 3 inches. They either contain well formed crystals of feldspar and quartz-the former occurring as Baveno twins-or crystals of quartz, to the total exclusion of the feldspar. 'This structure seems to indicate that, while the syenite is of deep seated origin, the then existing pressure was not so enormous as to prevent the formation of these cavities, which are more common in younger rocks of this class, such as the granite of the Castle Mountain mining district, Montana, described by Weed and Pirsson. The porphyry occupies a roughly triangular area,surrounded on two sides by the syenite. The most prominent part of the ridge (figure 1, plate 33), which faces the Ottawa river, forms the broad base. The rock shows considerable differeutiation of magma. West of the Devils garden it is a quartz-syenite porphyry, which consists chiefly of feldspar phenocrysts in a felsitic groundmass. 
To the south, in the apex of the triangle, the groundmass changes, becoming a dull compact one. The Devils garden, in part at least, is underlain by a variety transitional between the above rock and a quartzporphyry, which latter rock is developed east of the garden, continuing in that direction until the syenite is reached. The porphyry joints with ease, and the fragments form an irregular talus pile along parts of the northern slope. The contact of the porphyry and syenite was only seen at two points in the extreme east; elsewhere it is concealed by drift, and the approximate boundary line between the two rocks follows the deepest part of the irregular valley which separates them. A small dike of aplite cuts the syenite in the west. It is $2 \frac{1}{2}$ inches wide and was traced for 62 feet in a northeast direction. This was the only dike noted in the whole area.

A small exposure of Paleozoic rock occurs in the bed of river à la Graisse, about a quarter of a mile north of the mountain. The beds are transitional ones between the Potsdam and Calciferous formations; they represent a thickness of about 40 feet, and dip south at an angle of 4 degrees. This exposure of stratified rocks is the only one in the vicinity, and as they are not in contact with the igneous rocks nothing definite can be deduced from them as to the age of the latter.

In the southeast of the sheet and separated from Rigaud mountain by the valley of the Racquette river there is an exposure of Laurentian rocks, consisting of an area of gneiss overlain in part by an amphibolite. This outcrop of metamorphic rocks is due, according to Logan,* to an anticlinal axis, which divides longitudinally the great trough of Paleozoic rocks lying between the Ottawa and Saint Lawrence rivers. Mont Calvaire, a prominent outlier of the Laurentian. lies to the northeast of Rigaud, on the opposite side of Ottawa river. The rocks on the slopes facing . Rigaud are gneisses and amphibolites, much like the above, and it is probable that these older rocks on both sides of the river are closely related.

The drift which surrounds Rigaud mountain and separates it from the Paleozoic and Laurentian rocks has undergone a certain amount of assorting by water, the mountain being flanked by a broad zone of gravel and sand, which gradually pass into the sandy clays and clays of the plain. Erratics are more common on the northern margin than elsewhere, and consist chiefly of angular boulders of Potsdam sandstone. Fragments of Laurentian rock, together with those of Upper Cambrian age, are found generally though sparingly over the whole area.

In mapping, therefore, the contact between the igneous rocks and the drift was taken as the limiting line, except in such parts where it was

*Geological Survey of Canada, report of progress, 1851-'52, p. 8. 
quite obvious that the former was directly overlain by the latter. The rather abrupt slope the mountain presents along the greater part of the northern border favors the conclusion that the present boundary line is almost correct, and approximates closely the contact between the igneous and Paleozoic rocks. On the opposite side, however, the slope is very gentle, and in all probability the syenite extends half a mile or more farther south than the present boundary indicates. In its field relations, then, Rigaud mountain is seen in contact with no other rocks. From northwest to southeast it is separated from the Laurentian rocks by a band of drift-covered Paleozoic strata, which varies in width from 5 to 13 miles. In the southeast no Paleozoic rock apparently comes between the Laurentian and the syenite. It is only to the south and west that the Paleozoic plain is freely and uninterruptedly developed.

\section{Petrography}

\section{HORNBLENDE SYENITE}

The syenite in hand specimens is a coarse grained granitic rock, composed of feldspar and hornblende, with a small amount of gray vitreous quartz. When fresh, the feldspar, which makes up the larger part of the rock, is dark gray in color, with high luster and good cleavage. It weathers to a red or grayish white, and is usually stained along the cleavage planes by hydrated oxide of iron. The hornblende is black and brilliant, showing in prismatic sections the characteristic cleavage. Ordinarily the weathering processes have not affected it beyond a slight deposition of limonite along the cleavage planes. Under the microscope the rock presents the typical hypidiomorphic structure, and is composed essentially of microperthite and hornblende, with accessory plagioclase, augite, biotite, quartz, apatite, zircon, allanite, magnetite, and pyrite. The microperthite consists of an irregular intergrowth of orthoclase and plagioclase, the former greatly predominating. The orthoclase is quite turbid from kaolinization, while the plagioclase, which is probably albite, is usually clear and finely twinned according to the albite law, with an occasional development of the pericline twinning. A few individuals are twinned according to the Carlsbad law, with an irregular contact plane. Many of the larger plates of feldspar include differently oriented grains of hornblende and biotite, thus exhibiting the poikilitic structure. Associated with the microperthite in some slides is a small amount of finely striated feldspar in rounded oblong forms. It is older than the microperthite, being both included in and idiomorphic toward it. The maximum extinction along the twinning plane is 13 degrees, which would indicate oligoclase. It is altering from the interior, the peripheral 
zone being quite clear. The products are numerous shreds of kaolin, with an occasional minute grain of epidote or calcite. A mechanical separation by means of Thoulet's solution resulted in the oligoclase falling at a specific gravity of 2.62 , the greater part of the microperthite at 2.56 , and the remainder. which is probably almost pure orthoclase, at 2.52 .

The microperthite has a poor form, occurring in large irregular or thick lath shaped interlocking individuals, with smaller grains between. The only approach to idiomorphism is when the individual is in contact with the quartz. In this case there is a partial development of some of the crystal faces. The cleavage parallel to $c(010)$ is usually distinct; that parallel to $b$ (001) less so.

The hornblende is the common green variety, with an extinction angle of 20 degrees. The pleochroism is strong, the absorption colors ranging from deep green to pale yellow tone. Though usually fresh, in a few instances it is seen altering to chlorite either along the cleavage planes or zonally from the interior (plate 33, figure 2). The greater part of the mineral follows the ordinary law, crystallizing out before the feldspar, and is generally intergrown with augite and biotite. It is rarely idiomorphic, occurring in prismatic sections with terminal faces, poorly developed, in rounded basal plates and irregular grains. The larger individuals frequently exhibit a poikilitic structure, inclosing differently oriented grains of feldspar. The borders of the individuals are seldom smooth, but send out little extensions, which, penetrating the feldspar, in many cases develop into a skeleton crystal and form a graphic intergrowth with the latter mineral. Figure 2, plate 33, shows this structure; the skeleton crystal is in a feldspar individual, but joined to and in optical continuity with the parent grain. At other times the skeleton is not so connected, and then usually presents a delicate lattice-like structure, made up of slender prismatic rods connected at intervals by narrow transverse sections. The most striking structure, however, is when the hornblende occurs in forms strongly allotriomorphic toward the feldspar. In this case it fills triangular and polygonal interstices between the feldspar individuals, and is often associated with quartz. Figure 1, plate 34, shows this excellently, though for purposes of better illustration biotite is reproduced instead of hornblende. Ramsay and Hackman* have described a similar structure in the nepheline syenite of Pontelitschorr, in which ægerine assumes the form superinduced by the nepheline and feldspar, and in the same rock a poikilitic intergrow th of arfedsonite and æyerine occurs with the colorless constituents.

Augite, when present, almost invariably occupies the center of pris-

* Das nephelinesyenitgebiet auf der Halbinsel Kola, Fennia 11, no. 2, p. 127. 
BULL. GEOL. SOC. AM.

VOL. 12, 1900, PL. 34

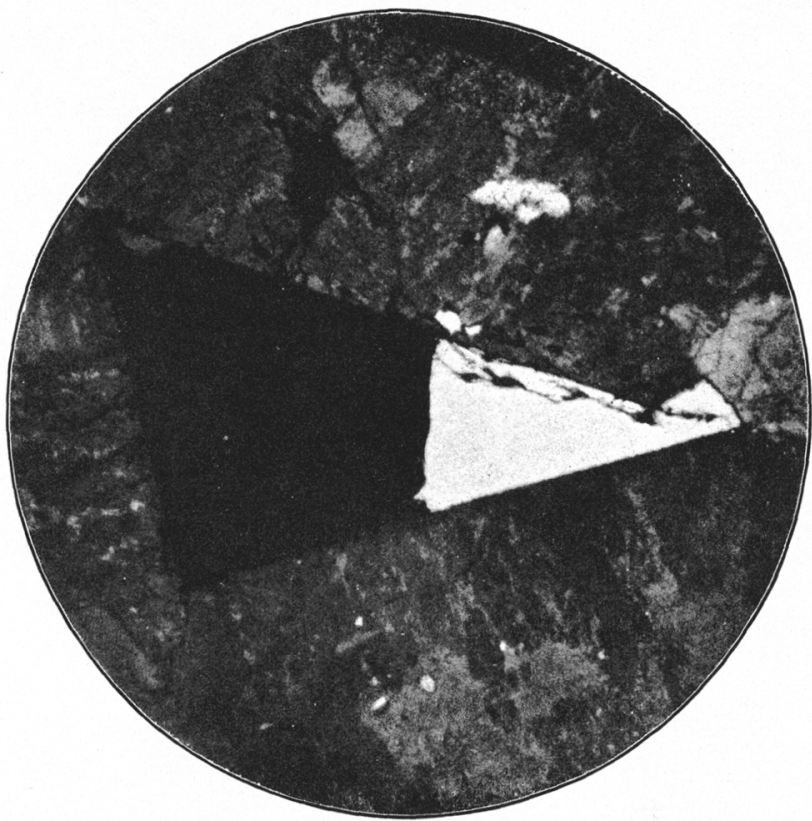

Figure 1.-Microphotograph of Rigaud Hornbiende-Syenite

Dark mineral is biotite and the white is quartz. Strong allotriomorphism of biotite towards the feldspar is well shown. Crossed nicols $\times 38$

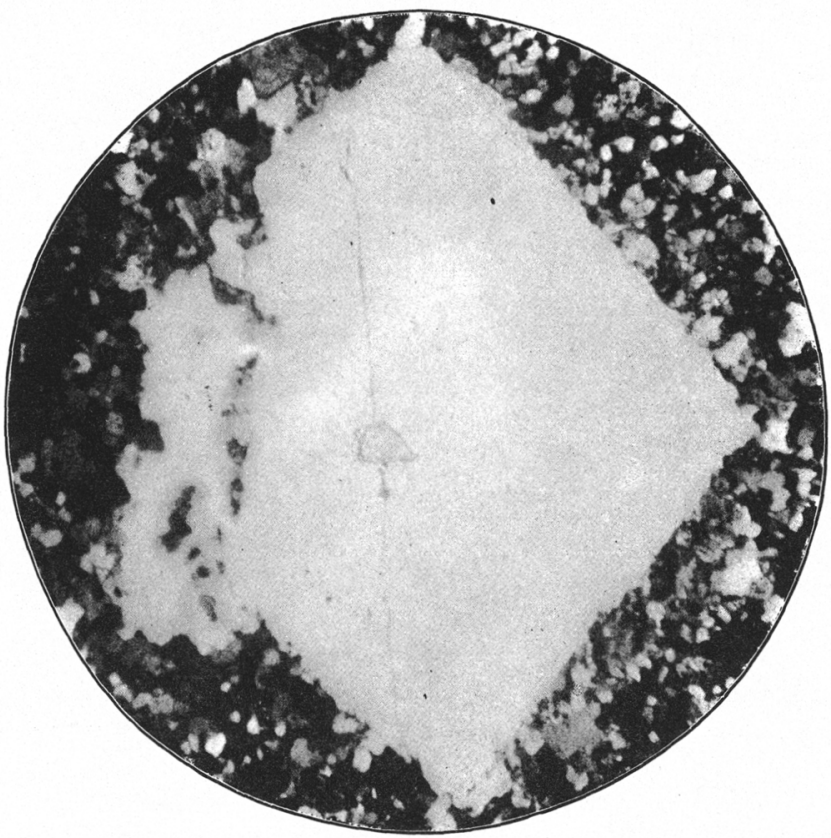

Figure 2.-Microphotograph of Rigaud Quartz Porphyry

Quartz phenocryst shows crenulated border due to secondary growth Crossed nicols $\times 47$ 
matic sections of hornblende with the cleavage planes of both minerals coinciding. It is very pale yellow in color, and has an extinction angle of 40 degrees. It has altered considerably along the cleavage planes, and lines of basal parting, to a yellow or brown serpentinous material with granular structure, low double refraction, and aggregate polarization.

Biotite is subordinate in amount to the augite; it is brown and strongly pleochroic in deep brown and pale yellow tones with a greenish tinge. With a few exceptions it seems to have been one of the first materials to crystallize out, and occurs intergrown with the hornblende or as inclusions in the feldspar. When included in the latter, small idiomorphic forms are common both in prismatic and basal sections. In some instances the biotite shows that strong allotriomorphism toward the feldspar, which has been previously noted in the hornblende (see plate 34, figure 1). Though generally quite fresh, a few individuals have partially altered the chlorite along the cleavage planes, while others have been partially or wholly bleached to muscovite with a faint greenish tinge and higher double refraction.

Quartz is present in but small amount and fills angular spaces between the feldspar individuals. Fluid and opaque inclusions are very numerous in some grains.

The following accessory minerals exhibit but slight variations to their usual mode of occurrence: Apatite in very small amount is present in idiomorphic, prismatic, and basal sections, rounded grains and needles being rare. Colorless zircon occurs in square basal sections, stout prisms with pyramidal terminations, and in large and small grains, the latter being sometimes arranged in radiate clusters. Basal sections show the uniaxial and positive character of the mineral as well as the cleavage parallel to $\infty P$, which is distinct. When the zircon is included in the hornblende or biotite it is always surrounded hy a pronounced pleochroic halo. The early crystallization of both the apatite and zircon is shown by their almost perfect form when included in the magnetite. Brown allanite is a rather common accessory in a few slides. It is found in graphic intergrowth with the feldspar, but usually occurs in rounded idiomorphic forms, included in the hornblende, and is al ways surrounded by a pleochoric halo. The individuals in $\infty P_{\infty}^{+}$sections are lengthened along the ortho-axis, and all are much traversed by cracks, the only distinct traces of cleavage noted being parallel to $o P$. Irregular zonal structure is invariable, and in all cases the interior is of a deeper color than the periphery. The pleochroism according to the zones is $\mathfrak{a}=$ deep brown, almost opaque; $\mathfrak{b}=$ brown, yellow ; $\mathfrak{c}=$ light brown, pale yellow. Nearly all the magnetite which is in considerable amount is included in the biotite and hornblende. In the former it sometimes occurs 
in small longitudinal plates arranged along the cleavage planes. A few grains of pyrite of cubic outline, with an alteration border of hematite, completes the list of constituents.

An analysis of the freshest rock procurable was made, the results of which are placed in the left-hand column, and, for the sake of comparison, one of the Plauen syenite* is given in the right.

I.

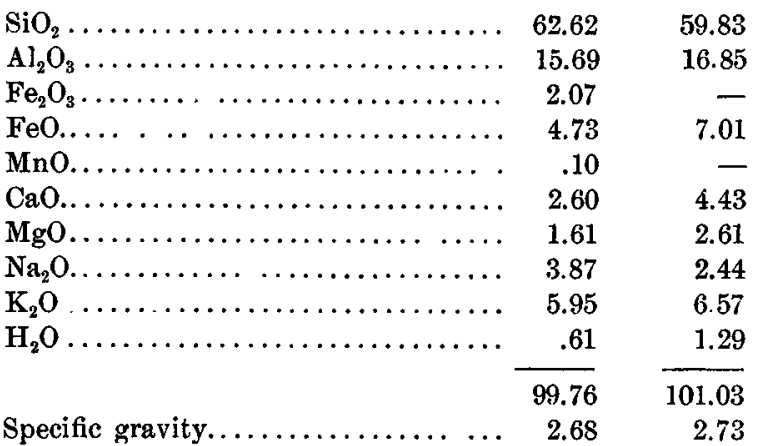

I. Hornblende syenite, Rigaud (analyzed by O. E. Le Roy).

II. Hornblende syenite, Plauen bei Dresden * (analyst unknown).

The analysis of the Rigand syenite bears out the result of the microscopic examination in that, as shown by the ratio of the alkalies, the orthoclase is the predominant feldspar in the microperthite. The rock is a normal syenite and compares favorably in composition with the typical rock of Plauen. The latter is higher in lime, iron, and magnesia than the former, and lower in silica, which is to be accounted for by its containing more of the ferro-magnesian constituent and less quartz. The total alkalies are almost the same for both rocks.

\section{QUARTZ-SYENITE PORPHYRY}

The porphyry, as has been previously mentioned, differentiates from a quartz syenite variety in the west of the mass to a quartz porphyry in the east, with an intermediate transitional band between.

Megascopically, the quartz-syenite porphyry consists of phenocrysts of feldspar, with a few of quartz, imbedded in a dark gray felsitic groundmass, which has an irregular conchoidal fracture. The feldspar, when fresh, is brownish gray in color, with good cleavage and high luster. It weathers to a pale red or grayish white. The phenocrysts have a poor form and vary considerably in size, from almost microscopic forms to 
those having a length of 1 centimeter. As a rule, they are very numerous and closely orowded together, but occasionally they occur very sparingly in bands and patches in the groundmass. Rounded grains of clear vitreous quartz are very subordinate in amount to the feldspar. The groundmass weathers to a light brownish gray, and the exposed rock often presents an angularly pitted appearance, due to the easy removal of the feldspar individuals.

Microscopically, the rock is composed of unstriated feldspar and quartz phenocrysts, with a few grains of plagioclase, biotite, hornblende, and zircon in a fine grained quartz-feldspar groundmass. Both the feldspar and the quartz occur in rounded idiomorphic and irregular forms, with crenulate borders and embayments filled with groundmass. The feldspar is apparently homogeneous, and presents a mottled appearance, due to kaolinization. It is evidently, from the analysis, a soda-orthoclase or anorthoclase. 'Twinning is rare and by the Carlsbad law only, with an irregular contact plane, which is usually filled with limonite. Strain shadows are common, and many individuals have been broken, especially where they are closely crowded together. A large number of phenocrysts were carefully freed from the base, and a mechanical separation made by means of Thoulet's solution. The freshest material fell at a specific gravity of 2.583 , which would indicate, as the analysis has, a soda-potash feldspar. A few small rounded oblong individuals of clear plagioclase, which is probably albite, and some small grains of partially altered hormblende and biotite, are included in the feldspar.

The quartz occurs very sparingly in large phenocrysts, and frequently holds inclusions, both fluid and solid, the latter being opaque. Strain shadows, cracked, and broken individuals appear in every slide, and, as in the case of the feldspar, are no doubt due to the strain exerted during the final solidification of the magma.

The effects of resorption and secondary growth, which is the characteristic structure in both the feldspar and quartz, are better developed in the latter. In both minerals the growth is quite regular, taking the form of a crenulate rather than vermiculate border around the original grain and in optical continuity with it. The primary and secondary material is sometimes separated by a dark line or string of magnetite granules. This structure shows that, in addition to the usual resorption which goes on in rocks of this class, there was a further change in conditions which permitted the corroded grains to take on new material identical in composition with the original. Figure 2, plate 34, is a typical example of a quartz phenocryst illustrating this structure.

Through the kindness of Mr Pirsson, the writer was enabled to examine a section of quartz-porphyry from Wolf butte, Little Belt mountains, 
Montana. In this rock the secondary growth of the quartz is much finer and better answers the definition of a coronal zone than does that of the Rigaud porphyry. In Weidman's description of the Utley metarhyolite* the secondary growth seems to be more identical, in form at least, with that of Rigaud. As this structure in the Rigaud porphyry presents no new features which have not been previously described by different writers, it is unnecessary to elaborate on the origin again.

The groundmass is composed principally of quartz and turbid feldspar, with a large number of idiomorphic grains of magnetite and a few of zircon, plagioclase, green hornblende, and brown biotite, the two latter being partially or wholly altered to chlorite. calcite, and limonite. The structure is microgranitic, and the allotriomorphic grains of feldspar and quartz are generally irregularly interlocked. Though very fine in grain, with a high power, the feldspar presents the same appearance as do the phenocrysts and is probably anorthoclase.

The quartz-syenite porphyry undergoes a variation in the southern part of the area, differing principally in the base, which megascopically is dull, compact, almost black in color, and weathers to a brownish gray. Microscopically, the feldspar and the quartz show the effects of resorption, but there has been no subsequent growth, the borders of the individuals being quite smooth. The groundmass is an extremely fine grained quartz-feldspar mosaic with a flow structure, accentuated by strings of magnetite granules, which coincide in direction with the flow. From this structure it is evident that this ty pe may be regarded as transitional between the quartz-syenite porphyry and a quartz trachyte.

\section{QUARTZ PORPHYRY}

The quartz porphyry is separated from the above by a broad band of transition rock which shows a gradual increase in the number of quartz phenocrysts, and a corresponding decrease in the case of the feldspar. In hand specimens the quartz-porphyry is a light gray felsitic rock weathering to a pale red, and is thickly studded with rounded phenocrysts of clear vitreous quartz. Under the microscope the same constituents are present that were found in the quartz-syenite porphyry, with the exception that the quartz is in very large amount, while the feldspar is represented by only a few phenocrysts in each slide. At the contact of the quartz porphyry and the hornblende syenite the former loses its characteristic structure, and occurs as a granular mosaic of quartz and feldspar, the latter being present largely in the form of Carlsbad twins. This contact facies is a little coarser in grain than would be expected.

* Pre-Cambrian Igneous Rocks of the Eox River Valley, Wisconsin, 1898, p. 29. 
Analyses of both varieties of the porphyry gave the following results:

I.

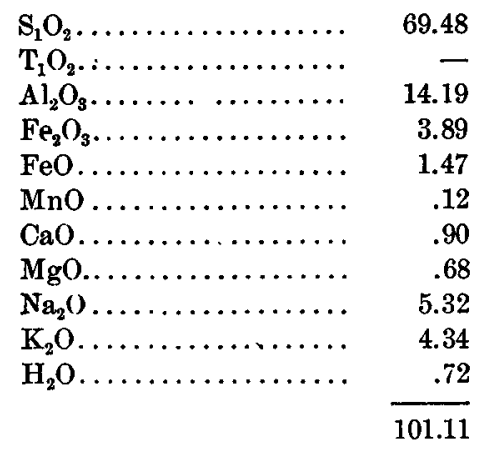

II. 77.30

\begin{tabular}{rr}
- & .22 \\
11.08 & 16.22 \\
3.91 & 1.98 \\
- & .16 \\
- & $\mathrm{Tr}$. \\
.68 & 1.32 \\
.45 & .77 \\
3.44 & 6.49 \\
3.22 & 5.76 \\
.28 & .30 \\
\hline
\end{tabular}

III.

6622

.22

16.22
Tr. $\quad \mathrm{P}_{2} \mathrm{O}_{5} \ldots \ldots, 0.10$

$\mathrm{BaO} \ldots \ldots . .29$

SrO........ .06

$\mathrm{SO}_{3} \ldots \ldots \ldots . .02$

Cl........... .04

Fl and $\mathrm{LiO}_{2}$. Tr.

Sp. gr., 2.63 Sp. gr., 2.64

$$
99.97
$$

$\mathrm{O}=\mathrm{Cl} \ldots \ldots . \quad .01$

99.96

I. Quartz-syenite porphyry, Rigaud (analyzed by 0 . E. Le Roy).

II. Quartz porphyry, Rigaud (analyzed by O. E. Le Roy).

III. Quartz-syenite porphyry, Bearpaw mountains, Montana (analyzed by H. N. Stokes).

The ratio of the alkalies in I shows that the soda molecule is the predominant one, and that the feldspar is undoubtedly anorthoclase. The ratio is comparable with that of the alkalies of III, in which rock the feldspar is also anorthoclase. In II the soda and potash are in almost equal amount, and as the feldspar is with few exceptions only present in the groundmass, the result indicates a close identity in composition between the feldspar of the base and the phenocrysts. The rather high percentage of iron is accounted for by the magnetite in the groundmass, while the small amount of the ferro-magnesian constituents is shown by the percentage of lime and magnesia.

\section{APLITIC DIKE}

The dike cutting the syenite is a rather coarse grained aplite, which when fresh is gray in color and weathers to a light reddish brown. Examined microscopically, it is seen to have a granular structure, and is made up of allotriomorphic grains of unstriated feldspar and quartz, with a few small individuals of plagioclase, apatite, and brown biotite. The feldspar is untwinned with the exception of a few Carlsbad individuals; it is very turbid and has numerous small flecks of brownish limonite along the cleavage and contact planes. Associated with it are a few striated individuals of oblong form, also much kaolinized. The former is probably orthoclase, the latter an acid plagioclase. The quartz 
is subordinate in amount to the feldspar, and frequently holds inclusions of the latter mineral in a poikilitic manner.

\section{LA URENTIAN HORNBLENDE-GRANITE GNEISS}

The metamorphic rocks shown in the southeast corner of the map are, as before stated, a hornblende-granite gneiss and amphibolite.

The gneiss is a light colored rock of medium grain, with a rude foliation of the essential constituents. Microscopically, it is composed of allotriomorphic grains of feldspar, hornblende, and quartz, with accessory apatite, iron ore, and brown sphene. The iron ore is generally surrounded by the sphene and is probably ilmenite. The feldspar is cryptoperthite, consisting of an extremely fine parallel intergrowth of orthoclase and ultramicroscopic plagioclase; it has a specific gravity of about 2.59, and resembles the feldspar in the orthoclase gneiss of 'Trembling mountain, Quebec. The hornblende is the ordinary green variety, with an extinction angle of 16 degrees. The quartz is clear, with but few inclusions, and usually has an undulatory distinction.

\section{AMPHIBOLITE}

The amphibolite is very dark in color, rusty in appearance, and disintegrates easily into a coarse sand. The microscope shows the typical structure of a recrystallized rock, the feldspar and hornblende occurring in polygonal forms arranged about a central grain. The other constituents are biotite, garnet, apatite, and magnetite. 'The feldspar is turbid and is altering along the cleavage planes. It is twinned in broad lamellæ according to the albite law, and gives along the twinning plane an extinction angle of 33 degrees, which indicates labradorite. This was checked by a mechanical separation, which shows that it has a specific gravity of 2.69. The hornblende, which is in large amount, is brownish green, pleochroic, and has an extinction angle of 20 degrees. Reddish brown, strongly pleochroic biotite is in smaller amount than the hornblende, but crystallized before it. Prismatic sections are lengthened in the direction of the $a$ axis and exhibit skeleton structure. The garnet is fresh, pale pink in color, and perfectly isotropic. It is much traversed by cracks and occurs in large, irregular individuals, either partly or wholly surrounding some of the hornblende and magnetite grains.

\section{Relation of Rigaud to the other Igneous Hills in the Vicinity}

The examination of Rigaud has shown that both in petrographic character and chemical composition the rocks are quite different from those composing the other hills on the same line. Two of these hills 
have recently been worked up, and it has been found that the prevailing syenite, which is an alkali rich one, is associated with a more basic rock, such as theralite or essexite. Unless, therefore, the character of the magma changed considerably, Rigaud could hardly be regarded as being genetically connected to the rest of the series. On the other hand, considering the fact that Rigaud is associated with the older crystalline rocks, it seemed advisable to visit the nearest eruptive in the Laurentian to ascertain if it would have any relations in common with Rigaud. Accordingly a brief examination was made of an area of hornblende syenite which occurs on the border of the Laurentian in the townships of Grenville, Chatham, and Wentworth, about 13 miles northwest of Rigaud.

\section{Grenville Area of Syenite and Porphyry}

The Grenville syenite occupies an area of 36 square miles, and was described by Sir William Logan.* It cuts the Laurentian rocks on three sides, but to the south it is overlain unconformably by the Upper Cambrian. Like Rigaud, it is pierced in the western part by a small pear-shaped mass of porphyry.

\section{Petrography}

\section{HORNBLENDE SYENITE}

Megascopically, the syenite bears a close resemblance to that of Rigaud, but contains a larger proportion of quartz, which increases in amount until finally the rock passes into a granite. Microscopically, it is composed of feldspar and hornblende, with accessory augite, brown biotite, quartz, apatite, zircon, and iron ore. The feldspar varies in different parts of the area from an unstriated one to a microperthite, both being much kaolinized. The unstriated feldspar is homogeneous, and occurs in thick lath-shaped and irregular individuals, while the microperthite consists of a parallel intergrowth of the orthoclase and a finely twinned plagioclase. The latter has a better form than the orthoclase, and from its association is older. It occasionally occurs as Carlsbad twins, and is sometimes intergrown with hornblende in a graphic manner. The cleavage of both varieties is not very distinct.

The hornblende is in comparatively small amount, the larger grains being quite irregular, but many of the smaller, when they are included in the feldspar, are idiomorphic. The pleochroism varies from deep green to pale yellow, and the extinction angle is 19 degrees. The strong allotriomorphism toward the feldspar is not so common as in the Rigaud syenite. Some individuals are intergrown with a pale yellow augite, in 
which case the latter forms the interior zone. Both minerals alter to a yellow serpentinous material.

The quartz occurs in rounded and angular grains, filling in interstices between the feldspar individuals. Fluid inclusions are numerous, and strain shadows invariable.

No analysis of the rock is available, but from the microscopical characteristics it seems to compare very closely with the Rigaud syenite.

\section{QUARTZ-SYENITE PORPHYRY}

The porphyry in hand specimens has a dark gray or reddish chert-like base, which holds a large number of phenocrysts of red feldspar. The rock joints with extreme ease into polygonal forms.

Under the microscope the following minerals were disclosed: Unstriated feldspar, quartz, and a few ragged plates of partially chloritized hornblende in an extremely fine grained groundmass, which, with the high power, resolved itself into a mosaic of quartz grains, and lath-shaped individuals of untwinned feldspar, the latter often being arranged in radiate clusters. The feldspar phenocrysts occur in rounded idiomorphic and irregular forms, and are apparently homogeneous, but very turbid. Twinning is not very common, but examples of both Baveno and Carlsbad twins are present in nearly every slide. The quartz phenocrysts are few in number, rounded in form, and hold numerous inclusions.

The usual resorption phenomena are pronounced both in the feldspar and the quartz, but only the latter shows secondary growth, the crenulated border being much finer than that found in the quartz of the Rigaud porphyry.

An analysis of the groundmass of the Grenville porphyry was published in the Geology of Canada, 1863 Report, and appears in the first column below.

\begin{tabular}{|c|c|c|}
\hline & I. & II. \\
\hline $\mathrm{SiO}_{2}, \ldots \ldots \ldots \ldots \ldots \ldots \ldots \ldots \ldots \ldots \ldots \ldots$ & 72.20 & 69.48 \\
\hline $\mathrm{Al}_{2} \mathrm{O}_{3} \ldots \ldots \ldots \ldots \ldots \ldots \ldots \ldots \ldots \ldots \ldots \ldots$ & 12.50 & 14.69 \\
\hline $\mathrm{Fe}_{2} \mathrm{O}_{3} \ldots \ldots \ldots \ldots \ldots \ldots \ldots \ldots \ldots \ldots \ldots \ldots$ & - & 3.89 \\
\hline $\mathrm{FeO} \ldots \ldots \ldots \ldots \ldots \ldots \ldots \ldots \ldots \ldots$ & 3.70 & 1.47 \\
\hline 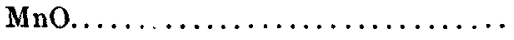 & - & .12 \\
\hline$\ldots \ldots \ldots \ldots \ldots \ldots \ldots \ldots \ldots \ldots \ldots$ & .90 & .90 \\
\hline $\operatorname{MgO} \ldots \ldots \ldots \ldots \ldots \ldots \ldots \ldots \ldots$ & - & .68 \\
\hline $\mathrm{Na}_{2} \mathrm{O} \ldots \ldots \ldots \ldots \ldots \ldots \ldots \ldots \ldots$ & 5.30 & 5.32 \\
\hline $\mathrm{K}_{2} \mathrm{O} \ldots \ldots \ldots \ldots \ldots \ldots \ldots \ldots \ldots \ldots \ldots \ldots \ldots \ldots$ & 3.88 & 4.34 \\
\hline $\mathrm{H}_{2} \mathrm{O} \ldots \ldots \ldots \ldots \ldots \ldots \ldots \ldots \ldots \ldots \ldots \ldots$ & .60 & .72 \\
\hline & $\begin{array}{r}99.08 \\
269\end{array}$ & 101.11 \\
\hline
\end{tabular}

I. Quartz-syenite porphyry, Grenville (analyst unknown).

II. Quartz-syenite porphyry, Rigaud (analyzed by O. E. Le Roy). 
Though the comparison of the analyses is hardly a fair one, it nevertheless shows that the two rocks are closely identical in composition. A proper analysis of I would no doubt demonstrate that satisfactorily. From the ratio of the alkalies in I, the feldspar of the groundmass is evidently a soda-orthoclase.

\section{Relation of the Rigaud and Grenville Areas}

The brief description of the Grenville syenite and porphyry has shown that they are closely related petrographically to the similar rocks of Rigaud. The relations of the two areas are farther considered by means of the following cross-section, which is a northwest prolongation of the line $A B$ on the Rigaud map.

Rigaud, it is seen, is thus separated from Grenville by a narrow band of Paleozoic rocks, which are supposed to overlie the Laurentian unconformably. It would seem, however, by no means improbable that the

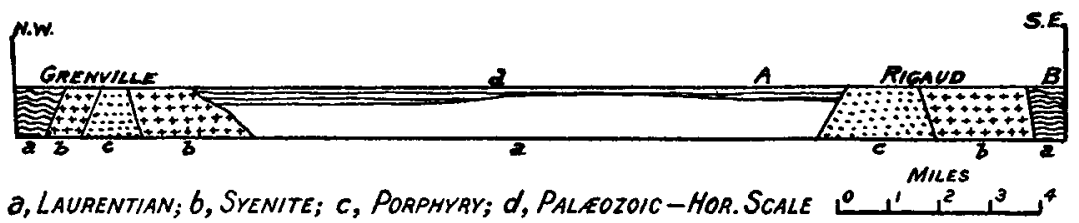

FIGURE 2.-Section from Rigaud to Grenville.

two areas might be continuous under the Paleozoic, and that the stratified rocks directly overlie the syenite instead of the Laurentian. Connected in such a manner, the eruptive mass would have a length of 20 miles, with a known maximum width of 9 . This would give an area by no means enormous when compared with other masses of similar occurrence in the Laurentian, such as the granite intrusion northwest of lake Saint Peter, river Saint Lawrence, which is 30 miles long and 12 miles wide in the broadest part. A point which favors this connection is that Rigaud, from its field relations with Laurentian outliers, is practically on the border of that system, and it is only to the south and west of Rigaud that the Paleozoic plain is freely and uninterruptedly developed. If the above association be true, then Rigaud is of pre-Potsdam age, and, as in the case of Grenville, the eruption took place after the processes which caused the metamorphism of the Laurentian system had ceased and before the deposition of the Potsdam sandstone.

\section{Summary ANd Conclusion}

Rigaud mountain is the most western of a line of hills of igneous origin. It differs from the others in that; while they are of post-Silurian age, its age is doubtful, as the contact with the Paleozoic is concealed. 
Rigaud is composed mainly of a normal hornblende syenite pierced in the northwest by an area of porphyry, which differentiates from a quartz syenite variety to a typical quartz porphyry.

The other hills, so far as known, consist of an alkali rich syenite, associated with a basic rock of the same petrographical province, such as theralite or essexite, both of which are totally different from the Rigaud rocks.

In the township of Grenville a mass of hornblende syenite of preCambrian age cuts the Laurentian and is itself pierced by a quartzsyenite porphyry, both rocks being closely identical with those of Rigaud. From the proximity of the two masses it seems probable that either they are continuous under the Paleozoic or that they are genetically connected.

It concluding, it may therefore be stated that in all probability Rigaud has no genetic connection with the rest of the series, but a definite conclusion is abstained from until such a time when our knowledge concerning the other hills is so increased as to permit of the range being studied as a whole. 